\title{
The Realization of Blended Teaching Model Based on Gradually Penetrative Method
}

\author{
Hu Xiuzhen, Pang Jing, Zhang Weiguang, Si Riguleng, Wu Yunmorigen \\ College of Science, Inner Mongolia University of Technology, Hohhot, China 010051 \\ *Corresponding author: Hu Xiuzhen, \\ E-mail: hh_xx_zz@163.com
}

\begin{abstract}
With development of assistant effects of the Internet plus in the education, assistant teaching methods, such as Micro course and MOOC gradually become part of course design. Blended teaching model basing on the Micro course becomes hot spot of education reform. However, it is a worth exploring question how teachers can be motivated to participate in teaching reform of the Micro course, to discuss fragmentation of knowledge and further to make the Micro course and to integrate fragmented knowledge into knowledge system. And ultimately, how blended teaching model based on the Micro course can be realized. We used a gradually penetrative method on basic courses teaching. Through establishing projects and creating competitions, we realized blended teaching model based on the Micro course and further improved teaching quality of basic courses.
\end{abstract}

Keywords-Basic course; Gradually penetrative method; Blended teaching model; Micro course

\section{INTRODUCTION}

On the March, 2015, the Prime Minister, Keqiang Li, put forward the plan, Internet plus. This plan drew educational world extensive attention, since it gave a ten years development program of education informationization on the level of ministry of education. Therefrom, Chinese education roundly entered a period of "Internet+education". The Micro course, MOOC, Flipped classroom and Mobile phone class are all applications of the "Internet+education". In other words, if we don't establish new concept of education, don't update ideas of education and don't innovate methods of education, we will fall far behind times ${ }^{[1]}$. Under the background of the open knowledge, we should do our best to guarantee students to get learning resources that they need anytime and anywhere. We should also take advantage of lifelong learning, independently organize the Micro course and develop characteristic Micro course that accord with students' characteristics and are closely related to teaching contents, so that ultimately, we can realize the blended teaching.

The traditional teaching model is that teachers talk and students listen. And then, students review course contents according to teacher's instruction and the textbook. With the development of education informationization, blended teaching model which combines advantages of both traditional education and digital education receives increasingly attention.
Since the blended model has complementary advantages, it achieves a better teaching effect. In this model, teachers play a leading role on guidance, enlightenment and monitoring during the teaching process. And at the same time, this model fully reflects students' initiativity, positivity and creativity as learning subject. Instead of replacing teachers with videos, the blended model is a way to increase interaction between teachers and students, and it aims at providing self-learning environment and individualized education to students, so that every student can keep up with the study schedule $\left.{ }^{[2,} 3\right]$.

It's beneficial most to develop the personalized and diversified blended teaching on basic courses since basic courses have more students and involve wider teaching contents. However, since several teachers are responsible for one basic course together, the development of blended teaching requires joint effort of all teachers. Or different requirements of teachers of the same course will lead to impossibility of giving students a reasonable evaluation. How can teachers accept the new education concept and take part in education reform? How can they learn and refine the Micro course and apply the Micro course to course teaching? Aiming at solving above questions, we take following steps. Firstly, we encourage young teachers to adopt modern teaching method first and then we make young teachers drive older teachers to accept modern teaching method. Secondly, using competition activities as propulsion means, the reform of teaching model will be speeded up by staged competition. Finally, taking teaching-reform project as an assistant impetus, we encourage faculties apply for relevant projects on any level and any class and realize blended teaching model under stress and impetus as quickly as possible. Except for courage we need patience more on the implementation of the reform. Practice has proven that gradually penetrative method is a reliable method to realize blended teaching model that based on the Micro course. 


\section{ENCOURAGING YOUNG TEACHERS TO USE MODERN TEACHING METHOD FIRST}

In the traditional teaching, we make older teachers guide Youngers. Older teachers would teach youngers techniques and methods of teaching. In adverse, older teachers will be guided by Youngers on making Micro course, one method of blended teaching since younger teachers accept new skills, especially internet assistant teaching faster. We take a two-way step on the work of concept guidance. On one side, research experts that devote themselves to the cloud teaching and Micro-Course are employed by our college to give reports. Modern teaching concepts are contained in reports, so that younger teachers can realize the importance of applying new teaching approach to classic basic courses. Younger teachers have advantages on mastering internet techniques faster. This is also a good opportunity for younger teachers to fully develop their interest on the internet and apply their internet skills to teaching research. On the other side, we encourage young teachers to attend teaching seminars, learn internet assistant teaching further and at last, apply digital techniques to teaching.

Regular seminars are necessary method for gradually penetration. After several discussions, teachers have clearly cognition about the Micro-Course. Core contents of the MicroCourse are composed by teaching videos. Micro-Course should also include assistant teaching resources that are relevant to teaching topic, such as, teaching design, teaching materials and teaching reflection. Although Micro-Course is different from traditional teaching resource, it is a new teaching resource that inherits from traditional teaching resource. According to knowledge points of the course, teachers rationally apply modern education techniques and equipment to make a Micro course that is 8-20 min long, or even shorter. The characteristics are that although videos are short, contents are rich, teaching information is clear, resource construction is scenario and that personalized and diversified teaching requirements can be satisfied ${ }^{[4,5]}$. Through gradually penetration and cultivation, a group of young teachers grew fast, and a bunch of software platforms and micro-courseware generated.

\section{SETTING UP CONTESTS AND BLENDED TEACHING PLATFORM}

Competitions are not only a platform for teachers to present themselves and learn from each other, but also can further promote the improvement of teaching quality of basic courses. On 2016, college of science grabbed the opportunity that created the competition of micro-course design of basic courses and fully aroused the enthusiasm and initiative of young teachers. All teachers those less than forty years old were participated in the competition of making micro-course. Under this stress and impetus, young teachers turned from passive teaching to active exploring teaching and research teaching. Through the first competition, we received some micro-course achievements and excellent young teachers. Besides, some of older teachers were increasingly interested in micro-course and were not afraid of digital teaching any more. At the same time, the reform of teaching model that young teachers drive older teachers to explore and develop blended teaching was preliminarily shaped. On 2017, we created the competition of micro course design of basic courses the same way and achieved better results than the first competition.

Through these two competitions, we perfected the competition technique standard of micro-course teaching design, such as, duration, resolution and formation of the video, the size of documents, voice frequency and caption of the video. And we refined teaching assistant materials, such as videos, exercises, quizzes and other teaching resources. The most important thing was that we collate knowledge points and knowledge points group of every basic course again. We also systematized knowledge points and improved overall teaching quality to a new level. After accumulating experience, a lot of young teachers attended micro-course competition and won prize on different level and class. And of course, blended teaching model was gradually matured.

\section{PROMOTING FURTHER DEVELOPMENT OF BLENDED TEACHING THROUGH SUBJECT APPLICATION}

With penetration of digital teaching idea and development of teaching competition, teachers' confidence on internet teaching increased, and their interest on teaching research enhanced. Both school and college encouraged subject application of teaching research and facilitated a fast development of the research of teaching. Nearly twenty subjects of digital techniques of basic courses were set up in the last two years. Five of them are national and provincial level. We got eminently achievements on the end of every subject. Thus, blended teaching is impelled forward.

The "lanmo" that is established by the ministry of education is a representative subject. Itself is a good platform that integrate online and offline teaching resources of basic courses. Online resources serve for course teaching, aiming at arousing students' learning enthusiasm and improving teaching effect. This platform also real-time monitor the whole teaching process and teaching procedure of every student with big data analysis so that we can continually make adjustment and receive alerts. Thus, the situation that learning result is only decided by the final exam can be avoided and Insufficient teaching duration can be made up. At present, Micro-Course are improved by Micro-Course competition. Production standard of teacher's advances continually and useful software is introduced. HD video studio rooms are built up and hundreds of Micro course that include homework and question answer have been completed. 


\section{GRADUALLY PENETRATIVE METHODS CAN REALIZE BLENDED TEACHING MODEL THAT IS BASED ON MODERN TECHNIQUES}

Trough two years' competition of Micro-Course design of basic courses, production skills of Micro-Course is further perfected and plenty of good quality Micro-Course videos are made. Assistant teaching methods, such as, "little bear course" and "cell phone course" are realized on "advanced mathematics" and "linear algebra". Digital Micro-Course platforms are built for "college physics". Blended teaching basing on Micro course is applied to "engineering mechanics". Knowledge points and knowledge points group of every basic course are collated, and knowledge system is specified. In addition, micro-course online platforms are unified. Teaching contents and methods are determined. Now, blended teaching represented by "little bear course", "rain course" and "lanmo course" operates normally.

"little bear course" is an assistant teaching method that based on Wechat platform and is created by our teachers. The course can be found, as long as students open the Wechat and input xxwkt1 in the search bar. And when students follow this Wechat public account, they can receive information and view history message form it. The contents of public account are composed by "advanced mathematics" and "linear algebra" now. The "advanced mathematics" includes five parts which

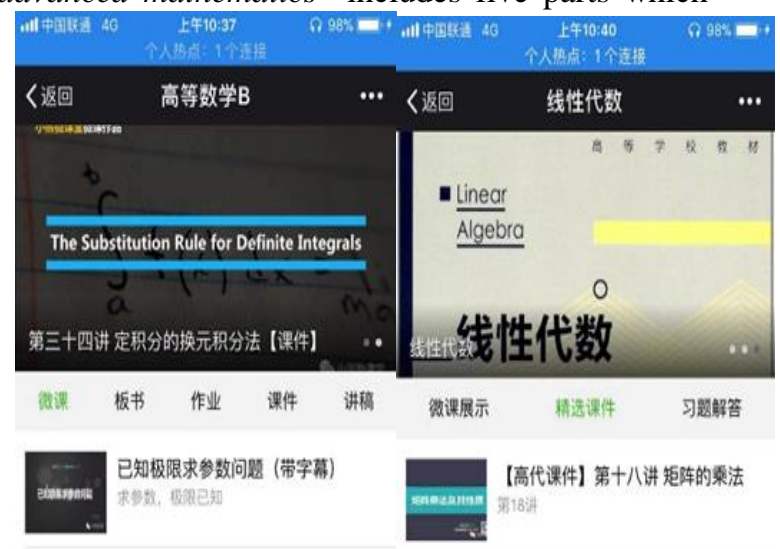

are micro-course, notes, homework, and courseware and lecture script. The "linear algebra" has three main parts that micro-course presentation, question answer and selected courseware. Now this platform owns plenty of teaching resources, such as micro-courses, full notes of one school year, handwriting scripts and solutions of exercises. These resources are not only beneficial to freshman, but also will be very helpful to those students who will take part in postgraduate entrance exam. Following are some interfaces of the Wechat platform. ( 1 and 2 are module interfaces, while 3 and 4 are booking interfaces. These interfaces show solutions to students' problems and practice questions separately. This platform has more than one thousand reading up to now). This Wechat platform can post courseware, notes and other teaching materials before class so that students can preview the class expediently. Then, high frequency problems will be sent to students as micro-course form. In this way, students study effects and teaching quality can be improved significantly. Taking advantage of Wechat platform, study efficiency is raised. Besides, communications and feedbacks between students and teachers are facilitated. The reading of articles on the platform reached more than one hundred times on average. The reading of some top articles reached more than one thousand. And more than three thousand students have already followed this public account.

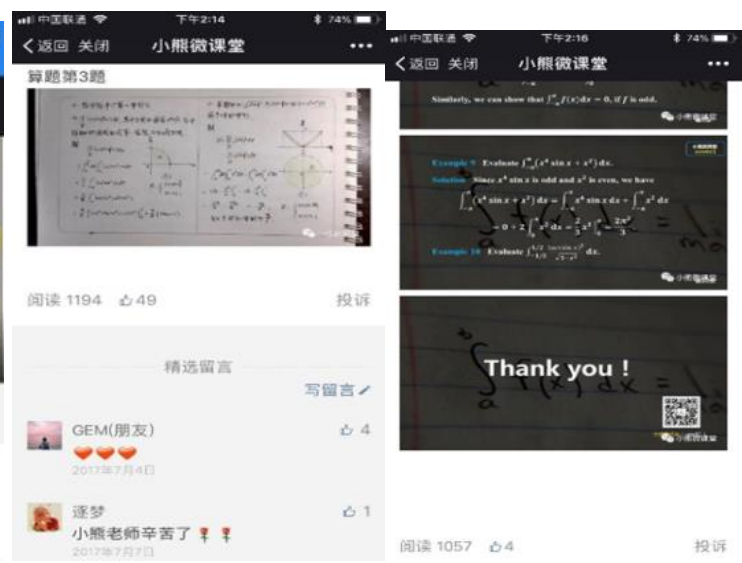

Fig. 1 "Little bear course" some interfaces of the Wechat platform

The "rain course" is an intelligent teaching tool. It puts complicated information into PowerPoint software and wechat platform. Therefore, "rain course" is realized basing on the most familiar software of students and teachers. Teachers can build up and manage class, make PPT courseware and post leaning materials on this platform. Students can preview and answer questions on the platform. The "rain course" increases communications between students and teachers and makes teaching more convenient. With "rain course", teachers not only can send videos exercises and preview courseware to students but can also learn learning condition of every student. It provides a perfect solution to the poor communication situation in the traditional teaching. Students can easily feedback contents that they didn't learn well on the platform after class. Teachers can help students to understand contents that they didn't master well on the class through sending learning materials and giving specific guidance. And teachers can also make adjustment to teaching contents in time.

The "cell phone course ("lanmo course")" is another APP platform that is developed basing on group. Comparing with "rain course", it has following advantages: firstly, it can share outside resources through link. Secondly, it has ability of signing up under any symbols. Finally, it can realize random call by the "shake" function of the cell phone. Besides, it includes several modules, such as, homework, vote and questionnaire, brain storm, questions discussion, test and so on. It also has conclusion of every week's courses. Followings are several representative screenshots. (They are micro-course, results analysis of test, using time of test and homework separately) 


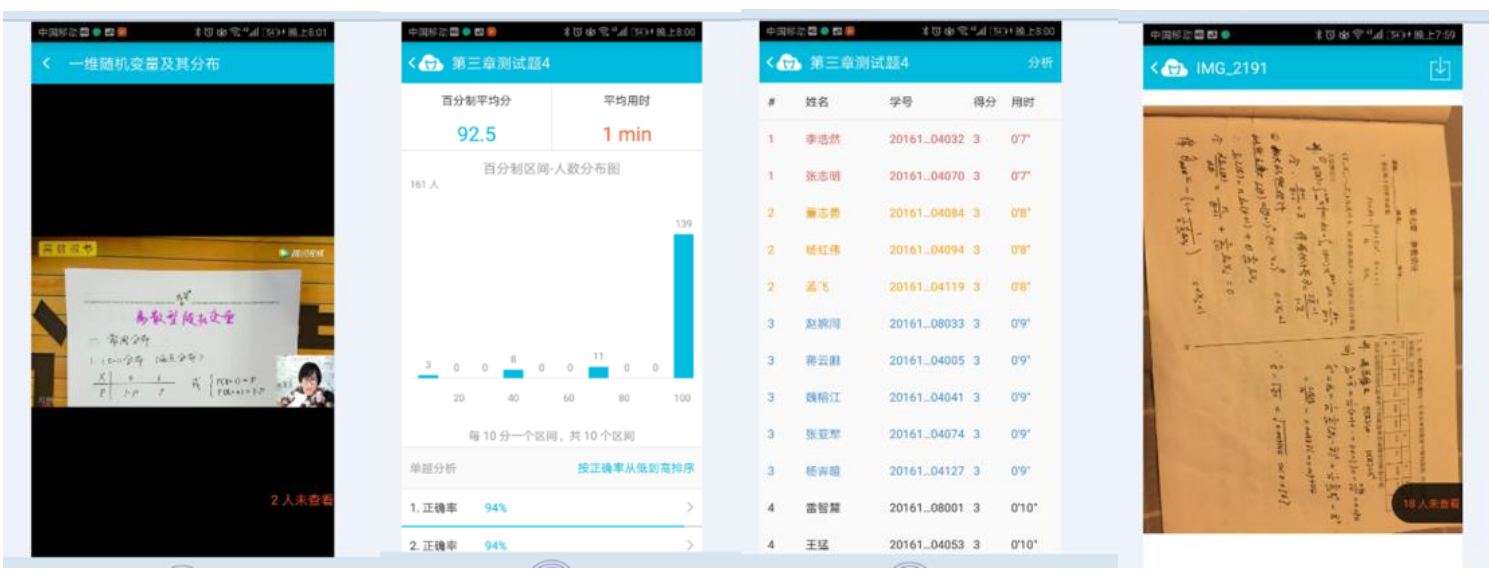

Fig. 2 "Lanmo course" some interfaces of the APP platform

Through these modern teaching methods, courseware of key contents and difficult contents, micro-course videos, conclusions and review problems are sent to students timely. It helps students understand and master contents better and extends teaching assistant methods from in class to after class. Students and teachers participate in teaching activities together. They experience, feel, comprehend and think. They become subjects and creators of courses. Not only teachers' creativity and positivity are fully developed, but also students' positivity and creativity of exploring and initiativity are immensely mobilized. Students have a huge enthusiasm on taking part in the reform of modern teaching.

\section{CONCLUSION}

Through several years effort on teaching research, blended teaching model played an important role on improving teaching quality of our basic courses of mathematics and science. All faculties actively participated in teaching reform and realized interactions between students and teachers. At the same time, we filled the huge gap between teaching and learning. At present, some other college faculties are continually asking and learning our experience. Furthermore, blended teaching model that is realized by gradually penetration methods are further generalized.

\section{ACKNOWLEDGMENT}

This work was supported by Inner Mongolia autonomous region education science planning project "Thirteenth Five years" (NGJGH201732); Inner Mongolia university of technology educational reform project (2016237, 2015105, 2016241).

\section{REFERENCES}

[1] Z. Guoqing, "'Internet +education" Opportunity, challenge and response". Guangming daily. Education weekly. Education space and time, 09, June 2015. (In Chinese)

[2] W. Rensong, "On the Teaching Reform of Public Basic Courses in Applied Universities under the Background of Flipped Classroom", Journal of Zunyi Normal College, vol. 8, pp. 126-130, August 2016. (In Chinese)

[3] P. Jianhua, W. Chunmiao, H. Liwei and Z. Yuqian, "Hybrid teaching research and practice of "Internet +"The Times" ,Science \& Technology Information, vol. 15, pp. 136-137, January 2017, (In Chinese)

[4] X. xi and X, Weimin , "Analysis on the problems of mixed teaching mode based on network", Journal of wuhan university of light industry, vol. 35 (2 ), pp. 114-117, February 2016. (In Chinese)

[5] T. Aili, "Teacher role transformation and comprehensive quality improvement under flip the classroom teaching mode", Teacher education research, vol. 27 (5), pp 84-88.2015. (In Chinese) 